\title{
Performing cathedral: Le Ballet des Ombres Heureuses as a case of multiple foregrounding
}

\author{
Eva Šlaisová
}

"Fireworks and light play could become theatre."

Jindrich Honzl

Using the theories of the Prague School, this study focuses on the video mapping $L e$ Ballet des Ombres Heureuses (Dance of the Blessed Spirits) ${ }^{1}$ created by the Belgian company ACT Lighting Design and projected on the facade of the Cathedral of Strasbourg and surrounding areas in 2017. Le Ballet des Ombres Heureuses will be presented here as a case of multiple aktualizace (foregrounding or topicalization), ${ }^{2}$ including that of the structure, function and sign.

\section{Aktualizace (foregrounding, topicalization)}

Jan Mukařovský first brought attention to the process of aktualizace in his article "An attempt at a structural analysis of an actor's figure" from 1931. He states: "a work of art [is] a structure ... of components aesthetically [automatized] and deautomatized [that is, uncommon or striking] and organized into a complex hierarchy that is unified by the prevalence of one component over the others" (MUKAǨOVSKÝ 2016a [1931]: 192). ${ }^{3}$

1 Le Ballet des Ombres Heureuses can be seen online at www.youtube.com/watch?v=pBA7FtCCBJU

2 The term aktualizace is commonly translated into English as "foregrounding," which was introduced by Paul Garvin in 1964. Garvin's term is problematic as it emphasizes spatial and static character of Mukařovskýs concept, rather than the temporal aspect. The importance of the temporal aspect of aktualizace was noted by Veronika Ambros 2008, who proposes that the term instead be translated as "topicalization" (for more information on this issue see ŠLAISOVÁ 2012). Being aware of its problematic connotations, I am using Garvin's term here, as it has been widely accepted and used in Anglophone theory.

3 Mukařovský (2016a [1931]) demonstrates the process of foregrounding; however, he does not use this term. The actual term was used a year later by HAVRÁNEK 1964 and MUKAŘOVSKÝ 1964. It is also important to note that the definition of foregrounding was not fixed in the texts of the Prague School scholars, but this concept was constantly redefined alongside the development of their theories. 
Mukařovský did not perceive the position of elements within a structure as fixed, but in constant motion as particular components change their positions; foregrounded components become automatized and different ones are foregrounded (MUKǍ̌OVSKÝ 2016a [1931], 1964). As such, he perceived foregrounding as the organizing principle of a work of art, as well as the energy setting structures/ art(s) into motion, and thus as the fundamental principle of the evolution of arts (MUKAǨOVSKÝ 1982b: 70-71; WINNER 2002: 84).

In the late 1930s and 1940s, Jan Mukařovský and Felix Vodička extended the concept of foregrounding by pointing out that the process of foregrounding includes not only the relationship between the author and a work of art, but also the relationship between a work of art and its recipient (e.g. MUKǍ̌OVSKÝ 1978 [1943]; VODIČKA 1982 [1941]). Depending on social background, age, prior knowledge, etc., each recipient foregrounds different components/ qualities/ features / signs of a work of art, thus establishing for himself a unique "aesthetic object" (MUKǍ̌OVSKÝ 1982a [1936]: 8). Hence, given that it encompasses both the creative process (the author) as well as the interpretative one (the recipient), foregrounding can be perceived not only as the key principle of the evolution of arts, but also of artistic communication as a whole.

\section{Light as aesthetic function}

"Public projection involves questioning the function ... [It] come[s] with the night, when the building, undisturbed by its daily functions, is asleep ..."

Krzysztof Wodiczko

Complementary to Mukařovskýs structure of components, the Prague School scholars introduced the structure of functions. They worked with the idea that a phenomenon can have a number of functions (aesthetic and extra-aesthetic) which are organized into a complex hierarchy, and that this hierarchy can change completely over time and/or upon entering a different social milieu (such as shoes, a Christmas tree, songs) (e.g. BOGATYREV 2016a [1936], 2016b [1936], 1971a, 2016c [1940] and 1971b). Moreover, they claimed that it is often not the hierarchy of elements ("form") which changes (which is actualized), but rather the hierarchy of functions (e.g. BOGATYREV 2016a [1936a]: 436; 2016c [1940]: 464). ${ }^{5}$

4 In 1936 Mukařovský transferred the concept of signifier and signified from the sphere of linguistics to sphere of art. According to him, "every work of art is an autonomous sign composed ... of artifact functioning as perceivable signifier ... [and] an 'aesthetic object' which is registered in the collective consciousness and which functions as 'signification'” (MUKAŘOVSKÝ 1982a [1936] 8-9). While the work of art-artifact remains always the same, the aesthetic object (meaning) is unstable and changes over time, upon entering different environments, etc.

5 One of the points of departure for Bogatyrev's (Mukařovskýs) theories was Jurij Tynjanov's theory of literary evolution. Tynjanov perceived evolution as "the change in interrelationships between the elements of a system - between functions and formal elements; [that is, as] the 'mutation' of systems" (TYNJANOV 1978: 
One of the areas which attracted the attention of the Prague School scholars from the functional point of view was architecture. According to Mukařovský and Bogatyrev, architecture fulfils several functions (BOGATYREV 2016b [1936]: 446; MUKAŘOVSKÝ 1966); however, in architecture the hierarchy of functions can never be dominated by the aesthetic one (MUKAǨOVSKÝ 1966: 201). If that were the case, Karel Teige explains, architecture would not be a piece of architecture, but a sculpture (TEIGE in MUKAǨOVSKÝ 1966: 201).

Following the semio-structuralist path of the Prague School scholars, Umberto Eco explored the functional model and a semiotic reading of architecture, claiming that, "architecture might be considered a system of signs" (ECO 1972: 266). As a sign, it consist of a signifier, that is an architectural object (such as a town hall, a house or a cathedral), and the signified, "tied by cultural codes to its function" (such as a cathedral being understood as a place of worship, or a town hall being understood as a place for the administration of local government) (CARLSON 1989: 7).

Nevertheless, Carlson, as well as Eco, Mukařovský, Vodička and others, argues that a "sign, once created, has a tendency to become the signifier for a new signified, by taking on new semantic overtones beyond the original" (CARLSON 1989: 7). This means that a cathedral could be turned into a place of profane ceremony and a town hall into a military storage facility. These new signifieds are activated through the foregrounding of a function which traditionally does not occupy the dominant position of an architectural object.

The Cathedral of Strasbourg, one of the oldest places of Christian worship, one of the most significant symbols of the city of Strasbourg, and the most popular tourist attraction in the city, becomes an object of such a re-signification, though a temporary one. On summer nights, the conventional signified and everyday, or to use the Prague School terminology, automatized hierarchy of functions is set into motion during video mapping productions. The aesthetic function is foregrounded - it dominates the structure; while the practical functions are diminished, or, to use Wodiczko's expression, "are asleep" (WODICZKO 1999: 47), and the cathedral is turned into a work of art and several "aesthetic objects" (in Mukařovský's sense).

However, the temporary loss of practical functions does not transform the cathedral into a sculpture, as suggested by Teige, but rather into a "living canvas" (MONKS 2014; WONG 2017: 188), "screen" (CUNIN 2017: 177) or "stage" (BASTIC 2014) depending on the artistic aim of the designers/artists as well as on the interpretation of individual audience members.

The video mapping Le Ballet des Ombres Heureuses draws on three theatrical forms: ballet, opera and shadow play, encouraging the perception of the facade of the cathedral as a stage. With regards to this show, the authors talk about "le théatre d'ombres" (shadow play theatre) (BONICHE 2017; VERMEUELEN 2017). On the one hand, shadow play theatre refers to the cathedral itself, as it has offered the spectacle of light

76). According to Tynjanov, the mutation of a system involved "not sudden and complete renovation or the replacement of formal elements, but rather the new function of these formal elements," resulting in diverse "functional systems" (TYNJANOV 1978: 77). 
and shadows for centuries: "Throughout the year, the play of shadows displayed [on the cathedral] intensifies as the sun rises [...]. Thanks to the seasons and the changing skies, the display is unique every day. With this performance [i.e. Le Ballet des Ombres Heureuses], shadow play theatre is modernized" (VERMEUELEN 2017). ${ }^{6}$

On the other hand, shadow play theatre refers to the ancient artistic form of shadow puppetry, which serves as the point of departure for the video narrative (the journey of the figure of the Silhouette) and some of the images of flat cut-out figures employed in the show (BONICHE 2017; VERMEUELEN 2017).

In addition, the title alludes to a part of Christoph Willibald Gluck's opera/ballet $O r$ pheus and Eurydice (1762, libretto by Raniero de Calzabigi) entitled Le Ballet des Ombres Heureuses. This contemporary work thus also refers to the ancient myth and offers an original adaptation of these genres. Taking inspiration from the ballet, the figure of Silhouette dances throughout the façade of the cathedral to digital music, which replaces Gluck's original music.

The audience's perception of the video mapping as a theatrical performance was further supported by the inclusion of purely theatrical (technical) components and conventions, such as lifting, or rather opening, the curtain at the beginning of the show and having the main shadow-play figure made a bow at the end of the performance when the audience applauded.

Given all these facts, it is clear that the authors aimed to create what Anthony Bastic calls, with regard to videomapping, "an outdoor theatre of light" (BASTIC 2014). In their approach, the façade of the cathedral and the whole Place du Chateau could be perceived as a manifestation of Jindřich Honzl's liberation of a stage from the constraints of the conventional theatre building, or in Bastic's terminology, from "black box" theatre (HONZL 2016b [1940]: 130-131; BASTIC 2014). As Honzl asserts: "it does not matter whether a stage is a structure or not" (HONZL 2016b [1940]: 129-130); what does matter for a stage is:

to "represent satisfactorily a dramatic space" (HONZL 2016b [1940]: 130),

to become "the embodiment of some dramatic theme or another in physical material and space" (HONZL 2016a [1933/34]: 301),

to "be a place of dramatic and poetic thinking" (HONZL 2016a [1933/34]: 301), or to become a place of “... action and ... becoming” (HONZL 2016a [1933/34]: 301).

Honzl's necessary conditions for a stage demonstrate varying degrees of referentiality, decreasing from the first statement to the last. In the first condition, the stage is a place which represents something else (realistic theatre) and in the last, it is a place for the presentation of the material quality (materiality) of bodies, light, architecture etc. In the former, the emphasis is on the signified (meaning), while in the latter, it is on the signifier (i.e., the material vehicle of the sign). Despite the differences, what all

$6 \quad$ In the original: “Tout au long de l'année, le jeu d'ombres projetées s'intensifie au fur et à mesure de la montée du soleil [...]. Grâce aux saisons, et aux mouvances du ciel, chaque jour le spectacle est unique. Avec ce spectacle, le théâtre d'ombres se modernise." 
these characteristics of the stage as a place of dramatic/poetic referential/non-referential action share is the fact that, in order for a stage to be a stage, it must be embodied in "physical material and space" and "perceptible to the spectator" (HONZL 2016a [1933/34]: 290 and 301).

Honzl's definition of stage as a place of action (drama) and becoming (poeisis) is vague, and thus allows for a variety of phenomena to be included under the umbrella of theatre/performance. According to Honzl's definition, theatre can be understood to include fireworks and light play (HONZL 2016a [1933/34]: 301, 1963: 161), as well as natural and artificial light and shadow plays which "set [an] object into action" (e.g. the cathedral) and present it in the "succession of changes" (HONZL 2016a [1933/34]: 301; see also MENOTTI 2013).

Transforming and/or perceiving the cathedral as a stage changes the common hierarchy of functions normally fulfilled by the cathedral, and transfers dominance from the practical functions of the cathedral to the aesthetic, that is, to the field of art.

\title{
Structure. Light in structure. Light as structure.
}

\author{
“... Light is not an afterthought. \\ It's something that's architectural. It's structure ..."
}

Robert Wilson

Considering the wall of the cathedral and the surrounding area as the stage suggests the perception of Le Ballet as a performance (modern shadow play theatre, light ballet and opera) and thus calls for interpreting it as a special case of foregrounding of theatrical structure (as analyzed by the Prague School scholars).

Prague School scholars considered theatre one of the most complicated artistic structures, as it incorporates individual arts and transforms them into its components. Yet, they claim that "... none of the components is absolutely necessary and fundamental for theatre," as the theatrical structure "is extremely changeable, and all the components assume the leading role during the course of development without any of them attaining permanent dominance" (MUKǍ̌OVSKÝ 2016c [1941]: 64). According to Mukařovský, if one were to claim that a certain component is a constitutive element of modern theatre (meaning the theatre of the 1920-1930s), then someone else would surely find a stage form in which the given component was missing and/or replaced by another (MUKǍ̌OVSKÝ 2016b [1937]: 213). As Honzl states, “... every historical period foregrounds a different component of the theatrical performance and the creative power of one factor can be replaced or suppress others without in this way decreasing the strength of the theatrical effect ... There are or there have been theatres without authors ...or ... directors ..." (HONZL 2016b [1940]: 140).

These days we are witnessing the rising position of light, which is becoming one of the dominant components of theatrical structure as its "creative power" can shape, suppress, diminish or replace other components. 
The theoretical texts of the Prague School touch upon this rising position of light within a theatrical structure, as well as artistic structure in general.

In Miroslav Kouřil's article "Theatre Space as a Visual Artist's Participation in Theatre," light is considered only as "a technological foundation". According to him, "we cannot consider lighting an independent artistic component of theatre because it is firmly and inextricably linked to the other details of the visual artistic side of the production and because it lacks dramatic independence" (KOUŘIL 2016 [1945]: 327; italics by E. Š.).

Yet, artistic praxis (reflected in the texts of Prague School) shows the opposite. Light is, of course, the technical foundation, as it enables the perception of a dramatic space (in conventional theatre buildings), but it is also much more. It is a material of artistic creation and as such, it is an important element of the theatrical structure, equal to music, actors, stage props, etc. In addition, it is not necessarily linked to other visual components; it can function on its own (or in relation to auditive components, such as music). What is more, it does not lack dramatic independence; on the contrary, it may become the vehicle of dramatic action.

As early as in his The Aesthetics of Dramatic Art, Zich claimed that in addition to this technical character, light has "obrazová funkce" (pictorial function), by which he meant that it can signify some elements of the external world as well as inner human states and actions. (I will discuss this later in relation to Zich's semiotics of light) (ZICH 1931: 268).

Linked with their idea of the mobility of theatrical signs and the liberation of signs from their conventional use (meaning in realistic theatre), Honzl and Mukařovský assert that light cannot necessarily be restricted to this limited use, but that light can suppress and replace other components of the theatrical structure, such as set design, costume, stage props or even actors (HONZL 2016a [1933/34]: 301; MUKAǨOVSKÝ 2016c [1941]: 64-65, 2016d [1946] 523-524). According to Mukařovský, "light serves as a powerful agent of movement, which can be found in all components of the set. It shapes the stage place, highlights the actors (or on the contrary, enables them to vanish), adds the finishing touch to their costumes, creates the set via projections, and finally, drawing the spectators' attention to changes in colour and intensity, wandering about the stage in the form of the beam of a spotlight, actually assumes the role of [...] an actor" (MUKAŘOVSKÝ 2016d [1946]: 523-524).

Placing light into the role of an actor, which is traditionally the most dynamic and active component of the theatrical structure, light was not perceived as a supporting element of dramatic action, but as its vehicle (MUKAǨOVSKÝ 2016d [1946]: 524), the source of theatricality (HONZL 2016a [1933/34]: 301), and thus the unifying or governing component of the theatrical structure.

Texts of the Prague School scholars encompass the whole range of positions which light has occupied in the theatrical structure. They demonstrate that the use of light ranges from technical to artistic. As an artistic device, light moves on the scale of Veltrusky's passivity and activity; that is, from part of the stage design to an agent of dramatic action (see VELTRUSKÝ 2016 [1940]). In addition, they state that light can be found in all the components of the set, supporting them or assuming their roles. In 
their discussions on light, the Prague School scholars brought attention to the fact topical in contemporary art - that light can replace any visual component of the theatrical structure, which results in the establishment of an extreme theatrical form - light theatre - in which all the traditional components, such as the set, props, actors, etc., are represented by light. In such a form, light is no longer a component of a structure, but a structure on its own, as suggested by Robert Wilson (WILSON and BELL 1994: 23). The question remains, however, whether this extreme form can still be considered an example of theatre, or if it is a new, autonomous, artistic form of Light Arts.

Le Ballet des Ombres Heureuses presents an example of such an extreme form (light theatre), in which light is foregrounded and occupies the dominant position, assuming the role of the majority of visual components of the artistic structure.

The show employs light in its various forms, including the beams of spotlights; static and dynamic projections, that is, images and videos; and shadow play of real and virtual objects. Static and dynamic projections of the forest, mountains or river (water) are used in the function of setting; some props, such as stars or balls, were also signified by light. In this setting, a shadow play figure (a part of the video narrative) wanders and thus becomes the main vehicle of dramatic action. In addition, a large number of abstract light shapes (the beams of spotlights and abstract projections) were employed in Le Ballet; these could be interpreted differently depending on whether the audience was able to perceive them as signs with a determinate meaning or just as signs with an indeterminate meaning, that is, as fleeting signifiers. As such, abstract light shapes ranged from those with specific referential meaning to those evoking feelings and emotions and supporting the atmosphere of the performance (which will be discussed in the next section).

\section{Light as sign}

“... the whole of stage reality - the dramatist's world, the actor's performances, the stage lighting - all these represent other realities.

The theatre performance is a set of signs."

Jindrich Honzl

If Honzl claims that light/lighting is a sign which stands for other realities, one must pose the question of how light in its simple abstract form can represent other realities.

One of the answers, and, I would say, one of the first semiotics of light, is proposed by Otakar Zich in his The Aesthetics of Dramatic Art and "Principles of Theoretical Dramaturgy." In the latter Zich asserts that: "Theatre light ... [is] for spoken drama what music is for opera" (ZICH 2016: 58). When one looks up what music is for opera according to Zich, one finds a complex classification of musical signs, which, if Zich is correct in his statement, should be applicable to light signs in theatre (video mapping).

Zich distinguishes two types of signs (obrazová schopnost) of music: "The pictorial (obrazivá) in the narrow sense of meaning based on the principle of similarity, and 


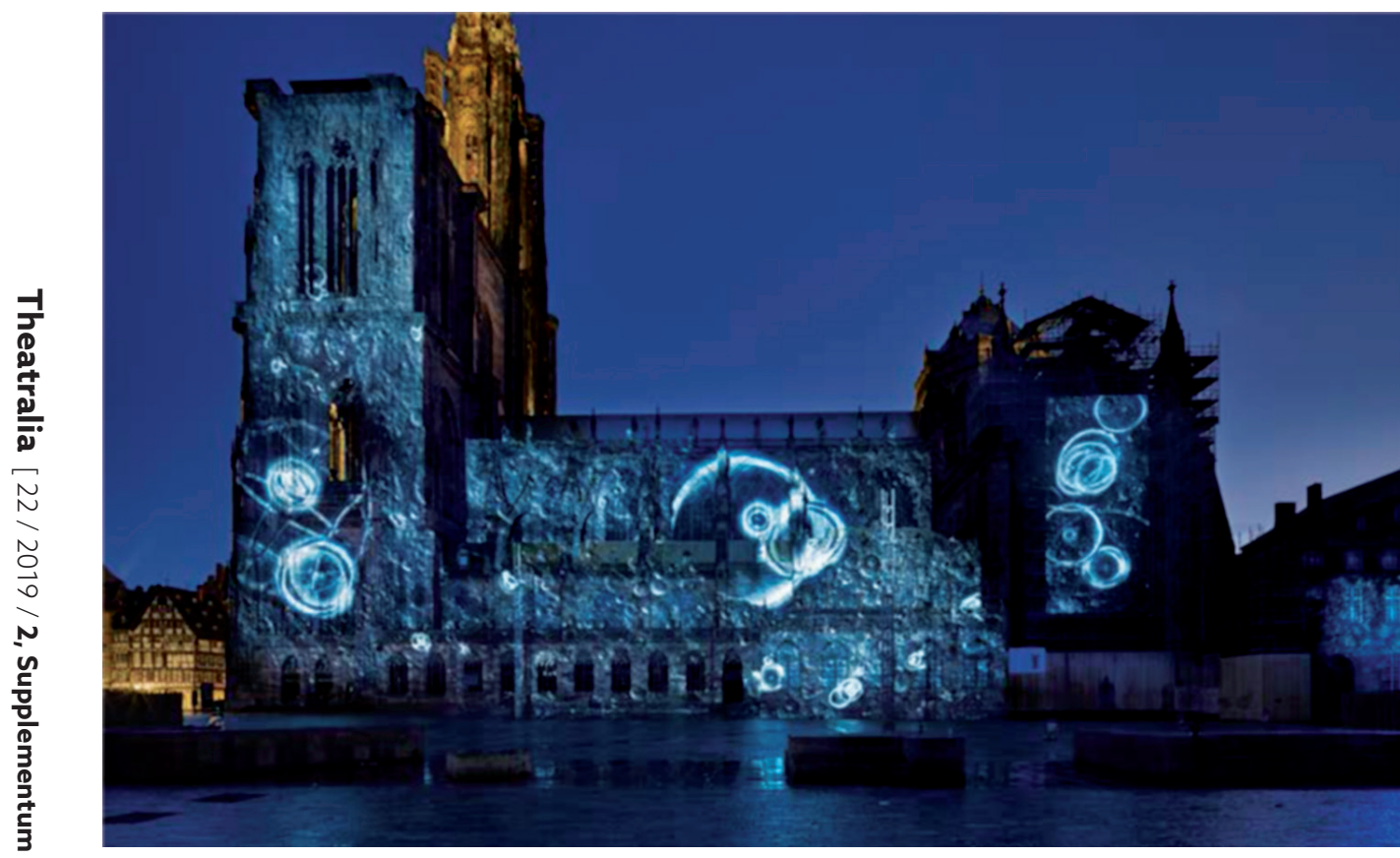

Fig. 1: Copyright ACTLD.com, Strasbourg 2017, Le ballet des Ombres Heureuses, Photo by Didier Boy de La Tour

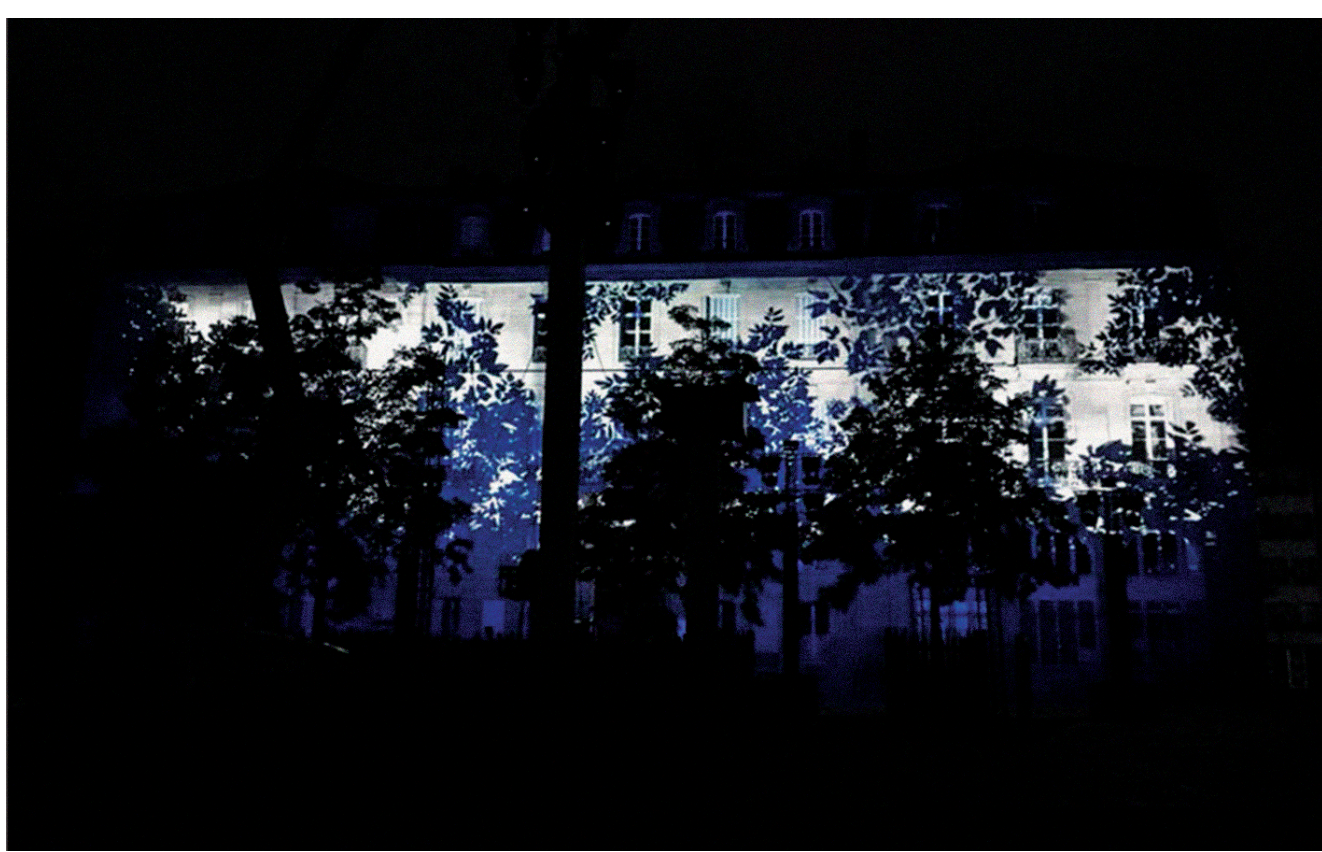

Fig. 2: Copyright ACTLD.com, Strasbourg 2017, Le ballet des Ombres Heureuses, Photo by Didier Boy de La Tour 
the expressive (vyjadřvac $\hat{\text { ) }}$ which is based on the principle of contiguity" (ZICH 1931: 278-279).

The expressive function of music lies in the fact that a listener is able to recognize that he has previously heard either in the given musical work of art or outside of it - a piece of music which he now hears in that work of art. That perceiver's original experience hearing that tune assigns meaning to the currently perceived composition or its parts (ZICH 1931: 294). Zich calls the allusion within a work of art the authorial musical quotation (hudebni citace autorisované), while allusion to another work of art is a conventional musical quotation (hudebni citace konvencionální).

Both types of quotations could be easily applied to the video mapping Le Ballet. In fact, Zich's expressive signs operating on the principle of contiguity were crucial for assigning meaning to more or less abstract light shapes of the show. The title plays a principal role in assigning meaning in Le Ballet; it became (or rather might become) "the semantic threshold" (HODROVÁ 2001: 243), which regulates perceivers' interpretation of specific components of the performance.

Those who are familiar with the title, but are not able to connect it with Gluck's opera, may perceive Le Ballet as "authorial light quotations," that is, as variations of the motif of shadows / dancing shadows. The motif of shadows occurs and reoccurs with twists throughout the course of the show; it ranges from traditional shadows of shadow play to abstract dancing shadows; from virtual projected shadows to shadows cast by real objects or represented by real objects, including people.

The realm of shadows was extended from the cathedral to the surrounding area, and thus the virtual world was expanded to the real world, encompassing and transforming its objects into signs. The audience was transformed into a group of shadows, who appeared in the middle of the dramatic space. The impression that the audience appears on the stage was even intensified by the fact that shadows, looking out of windows or balconies on the audience, were projected on the side buildings. Those perceiving the work were changed into the perceived; the observers of the dramatic world became its participants; and as such, the border between the stage and the auditorium was questioned and shifted.

Those, however, who were aware of the fact that the title alludes to a part of Gluck's opera Orpheus and Eurydice, called "Le Ballet des Ombres Heureuses," perceived the performance as a "conventional light quotation," that is, as a case of intertextuality. As Mukařovský states, in cases of intertextuality, it is not just a used quotation which enters a new work, but the whole semantic field of the original text, which enriches semantic layers of the new work of art (MUKǍ̌OVSKÝ 1948: 158). Hence, it is not just the scene "Le Ballet des Ombres Heureuses" (in which Orpheus enters the Elysium in search of Eurydice and moves among the group of dancers representing shadows / spirits), but the whole opera and even the original myth, which assign meaning to the components of the performance. As such, the myth becomes the unifying semantic power of the show.

Due to the contiguity between the opera/myth and Le Ballet, a second layer of meaning is created. The main shadow-play figure is not perceived as an "authorial quotation," 


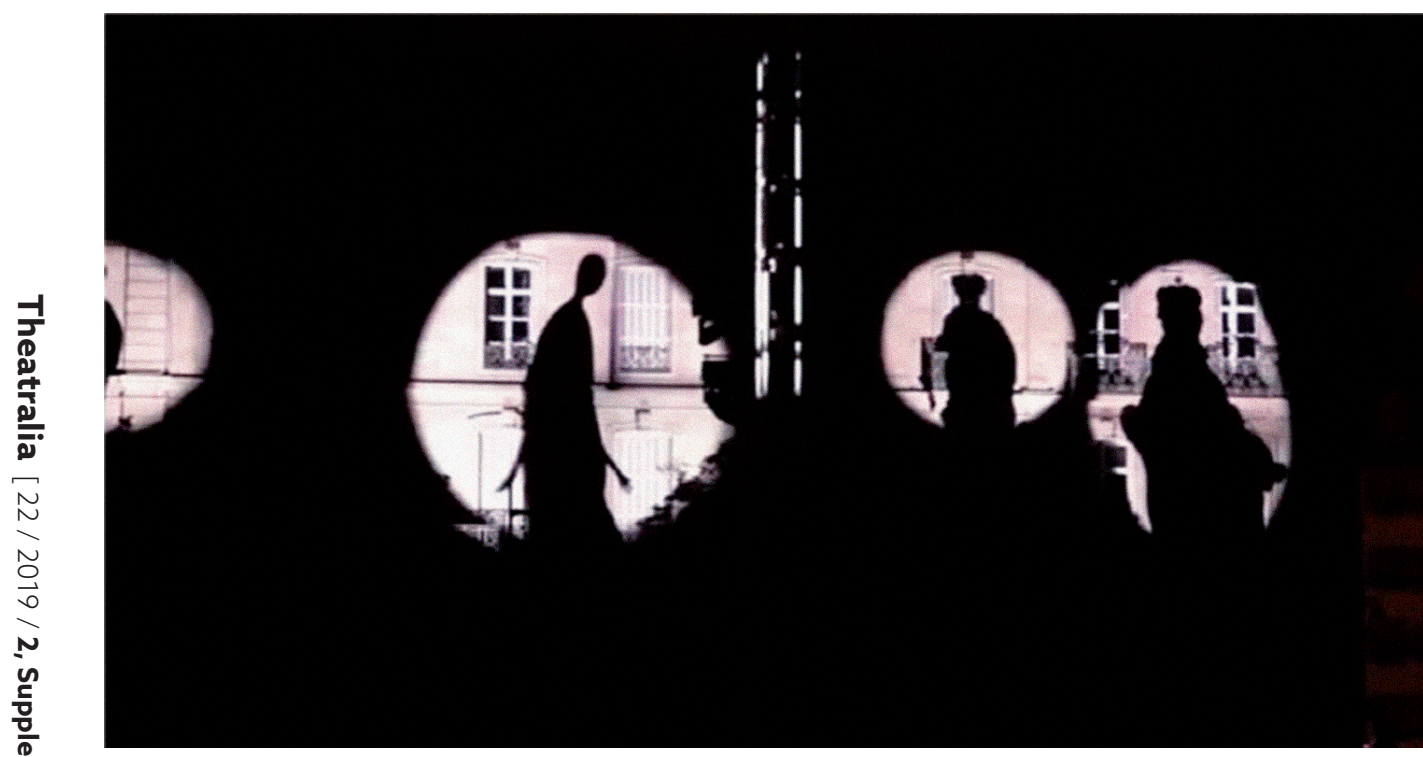

Fig. 3: Copyright ACTLD.com, Strasbourg 2017, Le ballet des Ombres Heureuses, Photo by Eva Šlaisová

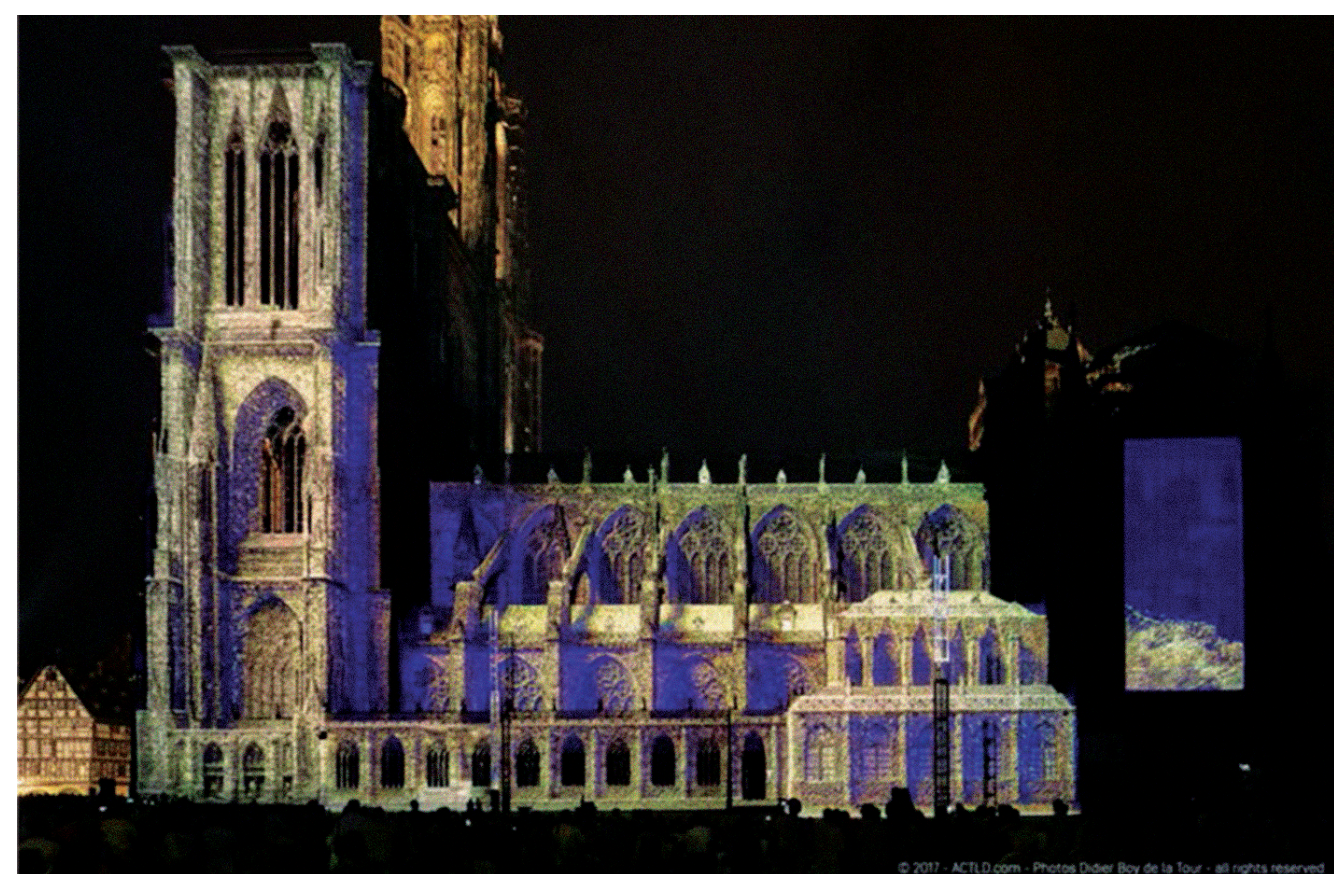

Fig. 4: Copyright ACTLD.com, Strasbourg 2017, Le ballet des Ombres Heureuses, Photo by Didier Boy de La Tour 
that is, as one of the variations of the motif of shadows, but as the figure of Orpheus who is looking for Eurydice; and similarly, the abstract or other figural shadows, including the audience, are not just shadows, but the spirits of the underworld. In addition, projections in the function of the setting allude to the significant topoi of the myth, such as the forest, mountains and the river Styx. Orpheus walking and climbing on the mountain and moving to the west/moon side of the world may be interpreted as the journey of Orpheus to the world of death. In addition, the scene with Orpheus pulling a swan may be interpreted as taking Eurydice out of the underworld; the subsequent transformation of the cathedral into pieces, which are then taken away by the wind, can be seen as an allusion to Orpheus' failure and loss of Eurydice, who was transformed into the wind in the myth and returned to the underworld.

The connection between the video mapping Le Ballet and Gluck's opera does not only exist thematically, but also on a structural level. Calzabigi's libretto does not present the whole story, but only its most important parts; it begins with mourning for Eurydice, which is followed by Orpheus's journey to the underworld. In addition, Calzabigi's libretto does not employ side characters for the development of additional stories (as was typical of 18th century opera), but only cast Chorus, Amor, Eurydice and Orpheus. Last, but not least, a large portion of the text consists not of dialogues, but monologues expressing the internal world, that is, feelings, of Orpheus.

The fragmentation of the story, choice of key scenes from the myth, reduction of the number of characters, and emphasis on the lyrical parts, which are not expressed by words, but by light images, are also characteristic features of Le Ballet, which becomes an original adaptation of Gluck's and Calzabigi's work.

The video mapping actualization of Gluck and Calzabigi's Orpheus and Eurydice is exceptional, among other reasons, because it is not performed in an empty space, such as on a screen, canvas or empty stage, but in an already semantically rich place, that is a gothic cathedral and square. So, although I have pointed out the change of everyday functions and meaning of the cathedral, it still remains a place that is heavily charged with religious meaning, namely Catholic doctrine, and this becomes the backdrop upon which the Greek myth is presented. Specifically, the "house of God" is turned into and confronted by the Greek underworld.

What is more, a striking parallel is created between medieval mystery/resurrection plays, which took place in or in front of the cathedral, and the myth of Orpheus of Eurydice, which is, in fact, also a resurrection play, although of a different tradition. This clash of cultures, times and religions is provocative and estranges (in Shklovsky's sense) the conventional image and understanding of the cathedral. ${ }^{7}$

7 The aim of video mappings is Shklovsky's estrangement (ostranenie), that is, to present an old, wellknown place in a new light and draw the audience's attention to its history, aesthetic aspects and creative possibilities. This means that video mapping removes an object (the cathedral) from the sphere of automatized perception and causes us to see it anew (SHKLOVSKY 1990). The way an object is removed from the sphere of automatized perception differs. The difference in approach is obvious when one compares, for example, Le Ballet with the 2015 show in the same location. In 2015, on the millennial of the existence of the cathedral, the main goal of the video mapping was to present the historic, cultural and aesthetic value of the cathedral in a new light and make us aware of these values. The whole show was based on the 
As shown, the title and contiguity which it establishes are crucial for the interpretation of Le Ballet, which is either perceived as an exploration of the theme of dancing shadows or as an adaptation or topicalization of the opera and (or) myth.

The principle of contiguity also played a crucial role in assigning meaning to the signs functioning on the principle of similarity, that is, Zich's pictorial capacity of music (obrazivá schopnost hudby).

According to Zich, the pictorial function (ability) of music lies in the principle of similarity, that is, in the resemblance between musical units/forms and various phenomena of our experience (ZICH 1931: 279), such as the sounds of nature and life around us, and human modes and actions. Feelings/emotions could be awakened by a particular quality of tones and their forms, their harmony and disharmony, which Zich refers to as the static or lyrical use of music. Actions are awakened by the progression of music in time, that is, though changes in intensity and speed, and changes in the sequence of tones. The facts of the external world may be represented through both the static and dynamic use of music. However, as Zich states, music is "devoid of ideas" (ideově bezobsážná), as it is an art which works with indeterminate signs and it uses only one type of signs, that is, auditive ones (ZICH 1931: 282). In order for the audience/listener to connect a particular tone or set of tones, which are rather abstract and can refer to several facts rather than just one, with a signified, one "must get an impulse" (ZICH 1931: 281). This impulse to assign a meaning to music comes from the presence of music or sound in the context of a performance and, importantly, from its connection with other signs, especially visual signs (such as light) (ZICH 1931: 281).

This means that, for example, a stormy piece of music in terms of the arrangement of tones can be associated with a thunderstorm in nature, if it appears in a specific context of the performance, for example, at the same time as flashing light. However, the same music could be interpreted as one's inner thunderstorm (for example, anger) if one perceives that music at the same time as a stage figure, onto which one can project these feelings/efforts evoked by music (ZICH 1931: 283). What Zich, in fact, states here is that the resemblance of music is indeterminate or ambiguous and in order to be associated with specific phenomena of the external world or with particular feelings and actions, it "requires the aid of several different sorts of contiguity" (VELTRUSKÝ 2012: 89).

Zich's analyses of the principle of verisimilitude in music could be also applied to light in theatre and video mapping. Similarly to music, light has only one type of signs, that is, visual signs, at its disposal, which are also "devoid of ideas" (ideově bezobsážnê). This means that light shapes and forms are abstract and may thus represent several things or stay in an abstract form as floating signifiers searching (or not) for their signified.

foregrounding of materials and architectural details of the cathedral, such as bricks, windows, stained glasses, rosettes, pillars, arcades, and sculptures, which were combined with animations exploring different stages of the cathedral's existence, including its construction, the Gothic period, and the contemporary period. This allowed the monumentality, beauty and exceptionality of the cathedral to be awakened and presented in an unconventional way. 
Like music, light is associated with a specific meaning in the context of a performance, in relation to other signs, visual and auditory alike.

In Le Ballet, music, or rather digitally processed sounds, played an important role in assigning meaning to light shapes in terms of the representation of the external world. In fact, sound was the only component of the artistic structure which helped to assign meaning to light. Through contiguity with sound, the audience could associate light "lines" with rain, abstract circles with water, or the falling down of the cathedral with the wind taking its pieces away. Sound helped to create a referential meaning of the first layer, which was a prerequisite for its connection with the second layer of meaning (that is symbolic, intertextual meaning).

Contiguity also played an important role in attributing meaning to the second type of Zich's signs based on the principle of resemblance, that is, the expression of feelings and actions (through light). Light - like music - has an ability to evoke feelings and lyrical moments through its qualities, such as colour, intensity, and shape. It can also create dramatic effect through the organization of light in time; that is, the changing of colours, shapes, and intensity. However, as Zich claims, in order for light to be interpreted as an expression of a specific feeling or effort, one must perceive a stage figure which functions as a vehicle for these feelings and efforts, simultaneously with the perception of light. In the case of Le Ballet, this was the shadow play figure of Orpheus, who could be perceived as the vehicle of emotions and actions expressed by light. Rather, the contiguity between Orpheus's dramatic story and light effects suggested a lyrical or dramatic reading of the use of light, but only for those who were familiar with the intertextual link.

Even though there is a parallel between the functioning of light and music in performance, as Zich proposed, there is a huge difference between assigning meaning in contemporary works of art, such as Le Ballet, and classical operas analyzed by Zich. In contrast to those operas with a fixed structure and rather straightforward process of semiosis, Le Ballet is a typical postmodern work of art, which could be characterized as Eco's open work with a field of possibilities or as a manifestation of Derrida's notion of the free play of signifiers. Free-floating signifiers prevail in Le Ballet and whether or not they will be associated with a signified depends mostly on a recipient and his/ her choice of the dominant. In fact, it is not the author who selects the dominant of such a work of art, but rather a spectator who, based on his/her knowledge, foregrounds different signs, or rather different parts/functions/meanings of Bühler's/ Mukařovský's model of artistic sign (BÜHLER 1990 [1934]; MUKAŘOVSKÝ 1948) Thus they perceive the same work of art, but establish for themselves a different "aesthetic object” (MUKAǨOVSKÝ 1982a [1936]).

If the perceiver's interpretation of the signs is governed by the principle of contiguity, indeterminate signs gain determinate meaning. Zich's conventional citation, that is the intertextual connection to Gluck's opera and thus to the myth of Orpheus and Eurydice, guides receivers to interpret Le Ballet as an original adaptation of this myth. The myth functions as the unifying semantic power of the performance, that is, as Mukařovský's intentionality, assigning referential meaning to more or less abstract light 


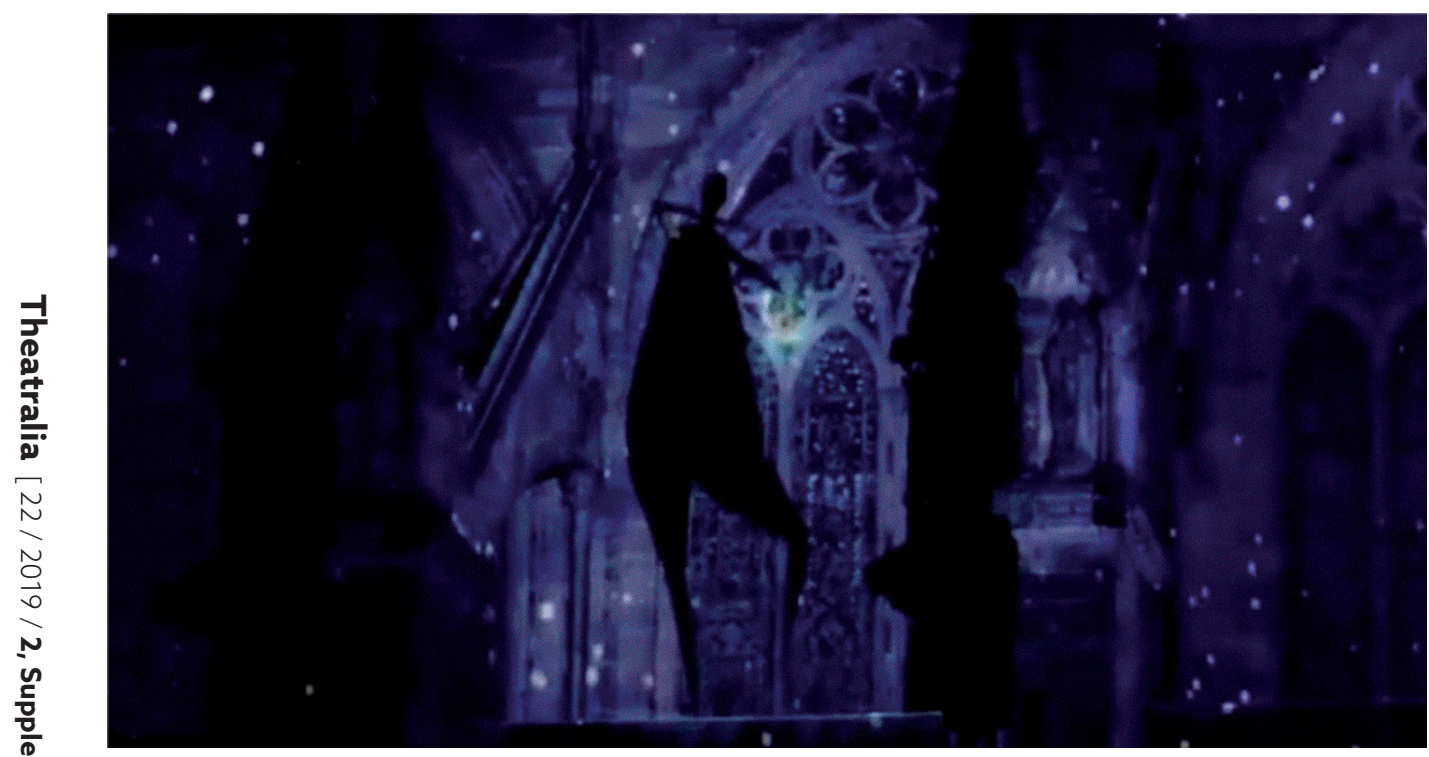

Fig. 5: Copyright ACTLD.com, Strasbourg 2017, Le ballet des Ombres Heureuses, Photo by Eva Šlaisová

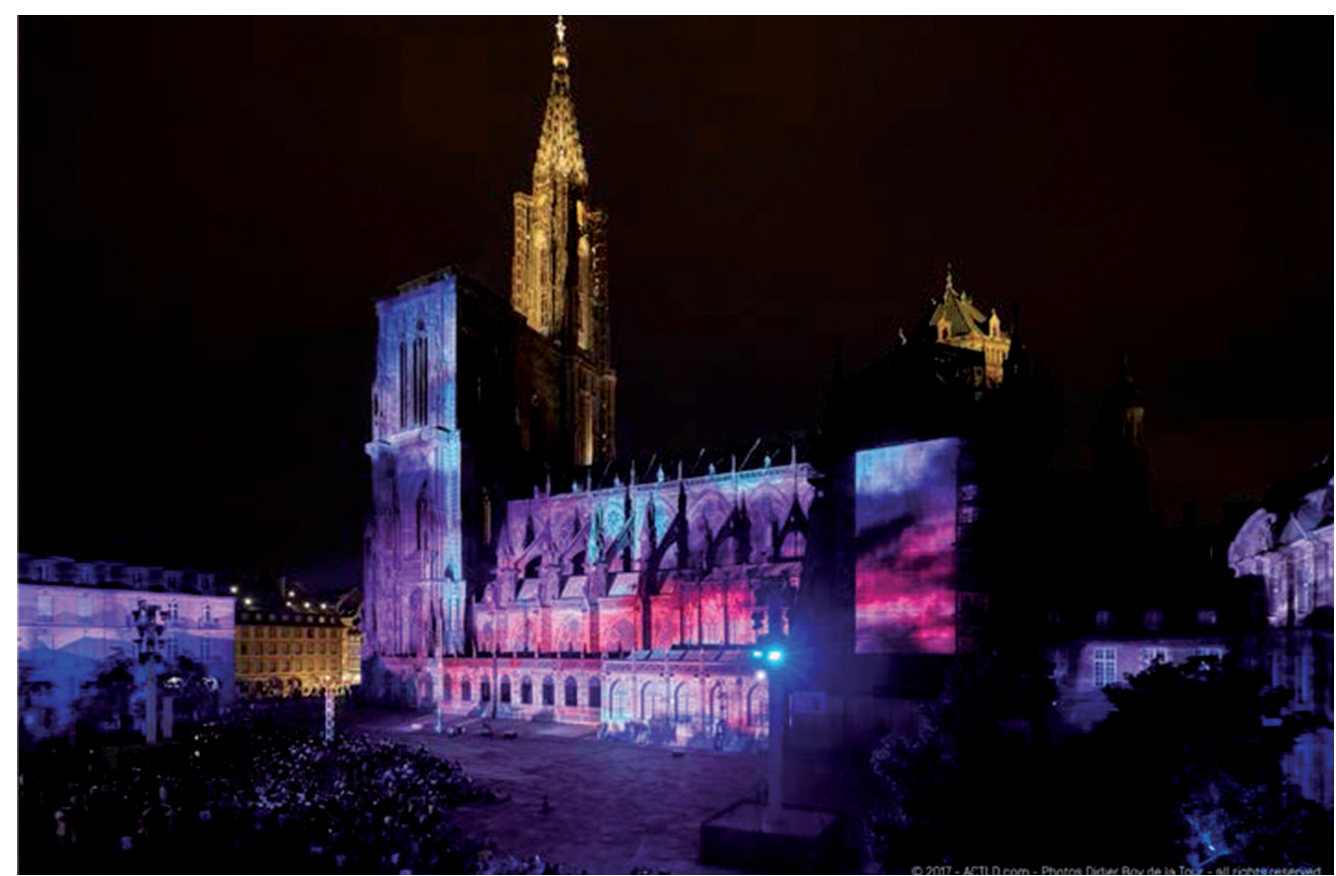

Fig. 6: Copyright ACTLD.com, Strasbourg 2017, Le ballet des Ombres Heureuses, Photo by Didier Boy de La Tour 
shapes. In this case, the facade of the cathedral and the surrounding area are perceived as the first type of Honzl's stage as they represent a dramatic space - the fictional world of the myth - and even a story, myth or tragedy.

In the case of the perception of Le Ballet as Zich's authorial quotation, that is, as a variation of the theme of dancing shadows, the cathedral-stage does not represent a story and a fictional world, but rather becomes a place, which in Honzl's words "embodies dramatic theme in physical material and space" (HONZL 2016a [1933/34]: 301); that is: the depiction of the theme of dancing shadows through the material of light and in the space of the cathedral and surrounding area.

However, if one is not able to anchor signs through Zich's two types of contiguity, this leads to a completely different understanding of Le Ballet. In this case, the performance presents only a succession of free-floating signifiers, which are "spiced" by a couple of iconic signs at several places of the performance. There is not any impulse to tie the meanings together, and thus the self-referentiality (Mukařovskýs unintentionality) of the artistic sign comes to the fore (together with the expressive function of the Bühlerian sign). The perceiver enjoys the materiality of light, its colours and shapes and their everlasting changes, "which stimulates ... unconscious emotions, conscious feelings ... and associations" (ABULAFIA 2016: 119). One perceives "action" and "becoming" of light in space and time, its constant movement and succession of changes, which is, according to Honzl, the essence of "the performance, the drama, the poem" (HONZL 2016a [1933/34]: 301). Consequently, one cannot speak about the façade of the cathedral as a stage in the previous two senses, but rather as a place of "dramatic and poetic thinking," which is based on the dramatic, poetic, and emotive qualities of light (HONZL 2016a [1933/4]: 301). In this view, the performance comes close to Kandinsky's stage synesthesia, which was theoretically introduced in the 1910s.

Le Ballet, as Mukařovský might have said, is based on the dialectic antinomy between determinacy and indeterminacy, intentionality and unintentionality, referentiality and non-referentiality. Which one gets into the foreground depends entirely on individual perceivers as well as what the cathedral performs. There is an unlimited field of possibilities, and an unlimited field of aesthetic objects, which are created from a work of art.

To conclude, using the example of the video mapping Le Ballet, I showed the possibilities of the Prague School theories for contemporary art, such as video mapping. The concept of the aktualizace (foregrounding) of functions demonstrated the change of the cathedral from a practical object into an aesthetic one; the foregrounding of the theatrical structure showed the rising autonomy and emancipation of light, resulting in the creation of "light theatre"; and last, this discussion has shown the importance of the process of foregrounding in the interpretation of a modern work of art (that is, of a sign and its signs).

In addition, working on this study, I discovered an unexplored field within the Prague School theories - that of light in theatre. Lack of interest in this subject may be a result of the fact that light was not the focus of specific studies; rather, comments on the use of light in theatre were spread throughout various texts. Nevertheless, when examined 
and seen together, as well as in relation to Zich's proposed application of music signs to light signs, one gets the first semio-structuralist approach to the study of light and a significant theoretical testimony about the increasing dominance of light within the theatrical structure, as well as in the structure of arts in general.

\section{Bibliography}

ABULAFIA, Yaron. 2016. The art of light on stage: lighting in contemporary theatre. Abingdon, Oxon/New York: Routledge, 2016.

AMBROS, Veronika. 2008. Prague's experimental stage: laboratory of theatre and semiotics. Semiotica 168 (2008): 45-65.

BASTIC, Anthony. 2014. Qtd. in Frank Hatherley 'Theatre of Light.' Stage Whispers (May/June 2014). Available online at www.stagewhispers.com.au/articles/191/theatre-light.

BONICHE, Julie. 2017. Qtd. in Romane Porcon. "Strasbourg: Le ballet des ombres heureuses s'invite sur la cathédrale pour le spectacle d'été." France Bleu Alsace (24 June 2017). Available online at www.francebleu.fr/infos/culture-loisirs/strasbourg-le-ballet-des-ombres-heureuses-sinvite-sur-la-cathedrale-pour-le-spectacle-d-ete-1497630955.

BOGATYREV, Petr. 2016a [1936]. Folk song from a functional point of view. In David Drozd, Tomáš Kačer and Don Sparling (eds.). Theatre theory reader. Prague School writings. Prague: Karolinum Press, 2016: 428-440.

BOGATYREV, Petr. 2016b [1936]. Clothing as sign. In David Drozd, Tomáš Kačer and Don Sparling (eds.). Theatre theory reader. Prague School writings. Prague: Karolinum Press, 2016: 441-447. BOGATYREV, Petr. 2016c [1940]. The extra-aesthetic function of folk theatre. In David Drozd, Tomáš Kačer and Don Sparling (eds.). Theatre theory reader. Prague School writings. Prague: Karolinum Press, 2016: 464-481.

BOGATYREV, Petr. 1971a. Př́íspěvek ke strukturální etnografii. In Jaroslov Kolár (ed.). Souvislosti tvorby. Praha: Odeon, 1971: 64-67.

BOGATYREV, Petr. 1971b. Vánoční stromeček na východním Slovensku. In Jaroslov Kolár (ed.). Souvislosti tvorby. Praha: Odeon, 1971: 71-75.

BÜHLER, Karl. 1990 [1934]. Theory of language: the representational function of language. Philadelphia: J. Benjamins Pub. Co., 1990.

CARLSON, Marvin. 1989. Places of performance: the semiotics of theatre architecture. Ithaca: Cornell University Press, 1989.

CUNIN, Dominique. 2017. Designing authoring software environments for the interactive arts: an overview of mobilizing.js. In Everardo Reyes-Garcia and Nasreddine Bouhaï (eds.). Designing Interactive Hypermedia Systems. Hoboken: John Wiley \& Sons, 2017: 131-183.

DROZD, David, Tomáš KAČER and Don SPARLING (eds.). 2016. Theatre theory reader. Prague School writings. Prague: Karolinum Press, 2016.

ECO, Umberto. 1972. La structure absente. Introduction à la recherché sémiotique. Paris: Mercure de France, 1972.

GLUCK, Christoph W. and Ranieri de CALZABIGI. 1955. Orpheus: An Opera in Three Acts. Original Italian Words by Ranieri de Calzabigi; French Adaptation for the Revised Version by Pierre Louis Moline; Music by Christoph Willibald Gluck; English Version by Edward J. Dent. London: G. Cumberlege Oxford University Press, 1955. 
GARVIN, Paul L. (ed.). 1964. A Prague School reader on esthetics, literary structure, and style. Washington, D.C.: Georgetown University Press, 1964.

HAVRÁNEK, Bohuslav. 1964. The functional differentiation of the standard language. In Paul L. Garvin (ed.). A Prague School reader on esthetics, literary structure, and style. Washington, D.C.: Georgetown University Press, 1964: 3-16.

HODROVÁ, Daniela. 2001. ... Na okraji chaosu: Poetika literárního díla 20. století. Praha: Torst, 2001.

HONZL, Jindřich. 2016a [1933/34]. Spatial concerns in theatre. In David Drozd, Tomáš Kačer and Don Sparling (eds.). Theatre theory reader. Prague School writings. Prague: Karolinum Press, 2016: 290-302.

HONZL, Jindřich. 2016b [1940]. The mobility of the theatrical sign. In David Drozd, Tomáš Kačer and Don Sparling (eds.). Theatre theory reader. Prague School writings. Prague: Karolinum Press, 2016: 129-146.

HONZL, Jindřich. 1963. Věda o umění, nebo vědecké uměni. Základy a praxe moderního divadla. Praha: Orbis, 1963.

KOUŘIL, Miroslav. 2016 [1945]. Theatre space and a visual artist's participation in theatre. In David Drozd, Tomáš Kačer and Don Sparling (eds.). Theatre theory reader. Prague School writings. Prague: Karolinum Press, 2016: 320-335.

Le ballet des ombres heureuses: grand spectacle de l'été 2017 à Strasbourg. Europtimist (6. 7. 2017). Available online at www.europtimist.eu/actualites/spectacle-ete-2017-strasbourg.

MENOTTI, Gabriel. 2013. Façadelifts: New Media installations, public space, and the negotiation of civic identity. In Richard Scullion, Roman Gerodimos, Daniel Jackson and Darren G. Lilleker (eds.). The media, political participation and empowerment. London/New York: Routledge, Taylor \& Francis Group, 2013: 130-141.

MONKS, Kieron. 2014. Lighting on the wall: world's most spectacular video projections.

$C N N$ (24. 6. 2014). Available online at www.edition.cnn.com/2014/06/18/tech/innovation/thebest-projection-mapping-in-the-world/index.html.

MUKAŘOVSKÝ, Jan. 1948. Básnické pojmenování a estetická funkce jazyka. Kapitoly z české poetiky I: Obecné věci básnictvi. Praha: Svoboda: 1948: 157-163.

MUKǍ̌OVSKÝ, Jan. 1964. Standard language and poetic language. In Paul L. Garvin (ed.). A Prague School reader on esthetics, literary structure, and style. Washington, D.C.: Georgetown University Press, 1964: 17-30.

MUKǍ̌OVSKÝ, Jan. 1966. Problém funkcí v architektuře. In Květoslav Chvatík. Studie z estetitky. Praha: Odeon, 1966: 196-203.

MUKAŘOVSKÝ, Jan. 1976. Poetic reference. In Ladislav Matejka and Irwin R. Titunik. Semiotics of Art. Cambridge: MIT Press, 1976: 155-163.

MUKǍ̌OVSKÝ, Jan. 1978 [1943]. Intentionality and unintentionality in art. In John Burbank and Peter Steiner. Structure, Sing, and Function: Selected Essays. Yale University Press, 1978: 89-128.

MUKǍ̌OVSKÝ, Jan. 1982a [1936]. Art as semiotic fact. In Peter Steiner (ed.). The Prague School: Selected Writings, 1929-1946. Austin: University of Texas Press, 1982: 3-9.

MUKǍ̌OVSKÝ, Jan. 1982b. Structuralism in esthetics and in literary studies. In Peter Steiner. The Prague School: Selected Writings, 1929-1946. Austin: University of Texas Press, 1982: 65-82. MUKAŘOVSKÝ, Jan. 2016a [1931]. An attempt at a structural analysis of a dramatic figure. In David Drozd, Tomáš Kačer and Don Sparling (eds.). Theatre theory reader. Prague School writings. Prague: Karolinum Press, 2016: 192-198. 
MUKAŘOVSKÝ, Jan. 2016b [1937]. On stage dialogue. In David Drozd, Tomáš Kačer and Don Sparling (eds.). Theatre theory reader. Prague School writings. Prague: Karolinum Press, 2016: 212-215.

MUKAŘOVSKÝ, Jan. 2016c [1941]. On the current state of the theory of theatre. In David Drozd, Tomáš Kačer and Don Sparling (eds.). Theatre theory reader. Prague School writings. Prague: Karolinum Press, 2016: 59-75.

MUKǍ̌OVSKÝ, Jan. 2016d [1946]. On the artistic situation of the contemporary Czech theatre. In David Drozd, Tomáš Kačer and Don Sparling (eds.). Theatre theory reader. Prague School writings. Prague: Karolinum Press, 2016: 519-532.

SHKLOVSKY, Viktor Borisovich. 1990. Art as device. In Benjamin Sher. Theory of Prose. Elmwood Park, IL: Dalkey Archive Press, 1990: 1-14.

ŠLAISOVÁ, Eva. 2012. Aktualizace in English scholarly literature: interpretation, ignorance and misunderstanding. Theatralia 15 (2012): 2: 154-167.

TYNANOV, Jurij. 1978. On literary evolution. In Ladislav Matejka and Krystyna Pomorska. Readings in Russian poetics: formalist and structuralist views. Ann Arbor: Michigan Slavic Publications, 1978: 66-78.

VELTRUSKÝ, Jiří. 2016 [1940]. People and things in the theatre. In David Drozd, Tomáš Kačer and Don Sparling (eds.). Theatre theory reader. Prague School writings. Prague: Karolinum Press, 2016: 147-156.

VELTRUSKÝ, Jiří. 2012. An approach to the semiotics of theatre. Edited by David Drozd, et al. Brno: Muni Press, 2012.

VERMEULEN, Koert. 2017. Qtd. in Morgan Carlier, "Le ballet des ombres heureuses une immersion autour de la Cathédrale cet été.” Rue 89 Strasbourg (16. 6. 2017). Available online at www. rue89strasbourg.com/ballet-des-ombres-heureuses-cathedrale-strasbourg-121847.

VODIČKA, Felix. 1982. The concretization of the literary work. In Peter Steiner (ed.). The Prague School: Selected Writings, 1929-1946. Austin: University of Texas Press, 1982: 103-134.

WILSON, Robert and John BELL. 1994. The language of illusion. An Interview with Robert Wilson. Theatre Week (3. 1. 1994): 17-24.

WINNER, Tomáš G. 2002. Český strukturalismus v anglofonním a frankofonním světě: ignorování a nepochopení. Česká literatura 50 (2002): 1: 80-88.

WODICZKO, Krzysztof. 1999. Critical vehicles: writings, projects, interviews. Cambridge, Mass: MIT Press, 1999.

WONG, Liliane. 2017. Adaptive reuse: extending the lives of buildings. Basel: Birkhäuser, 2017.

ZICH, Otakar. 1931. Estetika dramatického umění. Prague: Melantrich, 1931.

ZICH, Otakar. 2016. Principles of theoretical dramaturgy. In David Drozd, Tomáš Kačer and Don Sparling (eds.). Theatre theory reader. Prague School writings. Prague: Karolinum Press, 2016: 34-35. 
